\title{
CARBON STOCK IN LITTER AND ORGANIC SOIL IN DRAINED AND NATURALLY WET FOREST LANDS IN LATVIA
}

\author{
*Aldis Butlers ${ }^{1,2}$, Andis Lazdins ${ }^{2}$ \\ ${ }^{1}$ Latvia University of Life Sciences and Technologies, Latvia \\ ${ }^{2}$ Latvia State Forest Research Institute 'Silava', Latvia \\ *Corresponding author’s email: aldis.butlers@silava.lv
}

\begin{abstract}
The aim of the study is to evaluate carbon stock in litter and organic forest soils in Latvia as well as to characterize accumulation of carbon in litter in afforested lands. The study is providing empirically valid information about soil and litter carbon changes for the National greenhouse gas (GHG) inventory by using data from National forest inventory (NFI), forest soil monitoring demonstration project BioSoil and other studies. The study proves significance of organic forest soil carbon pool in Latvia and demonstrates necessity to extend NFI incorporated forest soil monitoring program to improve data on soil density in wet organic soils, as well as to integrate data characterizing water regime in forests. The acquired data also proves that the conservative approach of calculation of carbon stock changes in litter in afforested lands applied in the Latvia's National GHG inventory avoids overestimation of $\mathrm{CO}_{2}$ removals. The data on litter carbon stock collected in this study is sufficient to estimate total carbon stock for stands dominated by most common tree species and long term impact of changes of species composition. Measurements of organic soil and litter thickness should be continued by NFI and integrated with more detailed soil monitoring to increase accuracy of carbon stock estimates and gather data necessary for verification of modelling data, particularly in afforested lands and due to change of dominant species.
\end{abstract}

Key words: carbon stock, litter, organic soil, forest.

\section{Introduction}

The net GHG emissions in Latvia in 2017 were 9.6 mill. t $\mathrm{CO}_{2}$ equivalents $\left(\mathrm{CO}_{2}\right.$ eq.) including Land Use, Land Use Change and Forestry (LULUCF) sector and 11.3 mill. $\mathrm{t} \mathrm{CO}_{2}$ eq. without LULUCF sector (Ministry of Environmental Protection and Regional Development, 2019). In 2018 Latvia joined the European Commission initiative 'A clean planet for all. A European strategic long-term vision for a prosperous, modern, competitive and climate neutral economy' (European Comission, 2018) by setting the GHG neutrality target in 2050. According to this proposal, the GHG emissions in Latvia have to be reduced by nearly 10 mill. $\mathrm{t} \mathrm{CO}_{2}$ eq. during the following 30 years. The LULUCF sector will have an important role in reaching this target because of considerable potential to decrease GHG emissions within the sector by implementation of the $\mathrm{GHG}$ mitigation measures in forest land, cropland, grassland and wetlands. In addition, LULUCF sector can contribute to the national target by providing replacement of fossil resources utilized in energy sector and other industries. Scientifically verified data on current status of carbon stock and the potential impact of mitigation measures are of particular importance to avoid misleading actions, as well as to avoid underestimation or overestimation of the projected GHG emissions (Rogelj et al., 2015).

According to the IPCC guidelines (Eggleston et al., 2006), litter is considered as emission neutral carbon pool creating $\mathrm{CO}_{2}$ emissions or removals in case of land use changes, as well as peat in naturally wet organic soils in forest lands. C-stock in organic soils have been evaluated in several previous studies (Lazdin̄š, Butlers, \& Lupiḳis, 2014; Lazdin̦š, Lupiḳis, \& Okmanis, 2014; Lazdinš \& Lupikis, 2014; Lazdiṇš, 2015). Carbon stock in litter layer in forest land in Latvia is $12.14 \mathrm{t} \mathrm{C} \mathrm{ha}^{-1}$ according to BioSoil results (Bārdule et al., 2009). However, results of previous studies does not provide comprehensive whole country representative data on $\mathrm{C}$-stock in litter and organic soils in forests stratified by soil moisture regime, stand age and dominant tree species.

NFI is the main source of activity data for National GHG inventory. NFI data is used to continuously improve the growth models (Lazdiňs et al., 2019) used to evaluate the impact of mitigation measures, e.g. afforestation or change of the dominant tree species (Bērziņa et al., 2018; Lazdiņa et al., 2019) on carbon stock in soil and litter. In order to acquire information necessary to characterize C-stock in litter and organic soil depending from stand properties, measurements of litter and peat layer depth were incorporated in NFI surveys in 2017.

The aim of the study is to evaluate carbon stock in litter and organic soils in drained and naturally wet forest as well as to characterize accumulation of carbon in litter in afforested lands, by aggregation of latest data on $\mathrm{C}$ stock from NFI surveys and previous studies.

\section{Materials and Methods}

Measurement of depth of organic soil and litter layer is done in NFI plots categorized as forest lands considering every plot as a single unit. NFI uses a permanently below ground marked $4 \times 4 \mathrm{~km}$ grid 


\section{Carbon content and soil density data applied in calculation}

\begin{tabular}{|l|c|c|c|c|}
\hline \multirow{2}{*}{ Layer } & \multicolumn{2}{|c|}{ Average data } & \multicolumn{2}{c|}{ Uncertainty range } \\
\cline { 2 - 5 } & density, $\mathrm{kg} \mathrm{m}^{-3}$ & carbon content, $\mathrm{g} \mathrm{kg}^{-1}$ & density, $\mathrm{kg} \mathrm{m}^{-3}$ & carbon content, $\mathrm{g} \mathrm{kg}^{-1}$ \\
\hline Litter & 76.6 & 540.6 & 15.9 & 5.0 \\
\hline $0-10 \mathrm{~cm}$ & 190.3 & 497.4 & 29.3 & 16.2 \\
\hline $10-20 \mathrm{~cm}$ & 206.1 & 489.1 & 34.3 & 23.5 \\
\hline $20-40 \mathrm{~cm}$ & 256.7 & 478.5 & 53.9 & 29.3 \\
\hline $40-70 \mathrm{~cm}$ & 319.5 & 447.2 & 71.4 & 35.3 \\
\hline
\end{tabular}

across all of the country with four permanent sample plots of $500 \mathrm{~m}^{2}$ size at each grid point. In total, 16,157 sample plots are used for calculations of land use and carbon stock changes. Each sample plot is surveyed once during a complete cycle of the monitoring of forest resources, i.e., once every 5 years. Borders of sample plots are constant during all NFI cycles, each plot on average represents about 400 ha of the country area including inland water bodies.

Depth of organic layer is measured with soil auger in 4 places (north, east, south and west direction) $2 \ldots 3 \mathrm{~m}$ from outer border of the plot. Total thickness of organic soil layer and litter is determined separately. Intercalibration training session is organized every spring before measurements to harmonize results. In case of unclear transition between mineral and organic layer, middle of transition layer is considered as depth of organic layer. Depth of organic soil is measured down to $70 \mathrm{~cm}$ depth, therefore in results instead of the total peat depth relative depth is expressed, respectively, $100 \%$ corresponds to $70 \mathrm{~cm}$ and $0 \%$ corresponds to $0 \mathrm{~cm}$. Data from 6,870 NFI plots surveyed in $2017 . . .2019$ are used for purpose of this study. The monitoring will be continued for at least 2 more years to survey all NFI plots in forest lands.

Recalculation from soil and litter layer to carbon stock is done using BioSoil demonstration project data (95 plots in total) on soil density and carbon content. Soil characteristics from 11 plots were selected as suitable and used in calculation. Additional soil bulk density data from other studies with organic soils were applied (Lazdiņš, Butlers, \& Lupiķis, 2014; Lazdiņš, Lupiķis, \& Okmanis, 2014; Lazdiņš \& Lupikis, 2014; Lazdinsš, 2015). Only 3 plots are located in wet organic soils, therefore average data (soil density and carbon stock) from organic soils are used in calculation. This may lead to overestimation of carbon stock in wet soils represented by limited number of plots. Summary of applied data are provided in Table 1.

Uncertainty is calculated as standard error of mean, uncertainty of area and average carbon stock per NFI plot is used to estimate uncertainties of the total and average values.

\section{Results and Discussion}

The evaluation of carbon stock in litter is split in 2 parts - carbon stock in afforested land and carbon stock in forest land remaining forest (forest land for at least 2 rotations). Summary of the calculation of carbon stock in litter in afforested land is provided in Table 2. For the most of the species considerable uncertainty is found in the data; however, there is a tendency of increase of average carbon stock in litter with increasing age of the stand. This trend is characterized by logarithmic regression (Figure 1). Average area weighed carbon stock in afforested lands up to 50 years age is $2.33 \pm 0.05 \mathrm{t} \mathrm{ha}^{-1}$, and average carbon stock in 20 years old forests in afforested lands

Carbon stock in litter in afforested land representing

Table 2 different age decades and dominant tree species ( $\mathrm{C}$ ha $\left.^{-1}\right)$

\begin{tabular}{|l|c|c|c|c|c|c|}
\hline \multicolumn{1}{|c|}{ Species } & \multicolumn{5}{c|}{ Age decade } & $\begin{array}{c}\text { Average } \\
\text { stock }\end{array}$ \\
\hline & 1 & 2 & 3 & 4 & 5 & \\
\hline Aspen (Populus tremula L.) & $4.36 \pm 0.65$ & $1.9 \pm 0.15$ & $4.61 \pm 2.2$ & $3.83 \pm 8.24$ & - & $1.9 \pm 0.04$ \\
\hline Birch (Betula pendula Roth) & $1.87 \pm 0.2$ & $2.18 \pm 0.01$ & $3.17 \pm 0.06$ & $5.08 \pm 5.13$ & $3.14 \pm 2.79$ & $3.6 \pm 0.01$ \\
\hline Grey alder (Alnus incana (L.) Moench) & $0.5 \pm 0.04$ & $1.22 \pm 0.03$ & $4.81 \pm 0.33$ & $2.76 \pm 0.54$ & $3.12 \pm 6.82$ & $1.83 \pm 0.01$ \\
\hline Spruce (Picea abies (L.) H. Karst.) & - & $1.3 \pm 0.09$ & $2.25 \pm 0.19$ & $5.75 \pm 0.05$ & - & $1.06 \pm 0.02$ \\
\hline Pine (Pinus sylvestris L.) & $0.19 \pm 0.22$ & $3.2 \pm 0.18$ & $0.44 \pm 0.31$ & $2.87 \pm 0$ & $4.66 \pm 10.02$ & $2.27 \pm 0.19$ \\
\hline
\end{tabular}




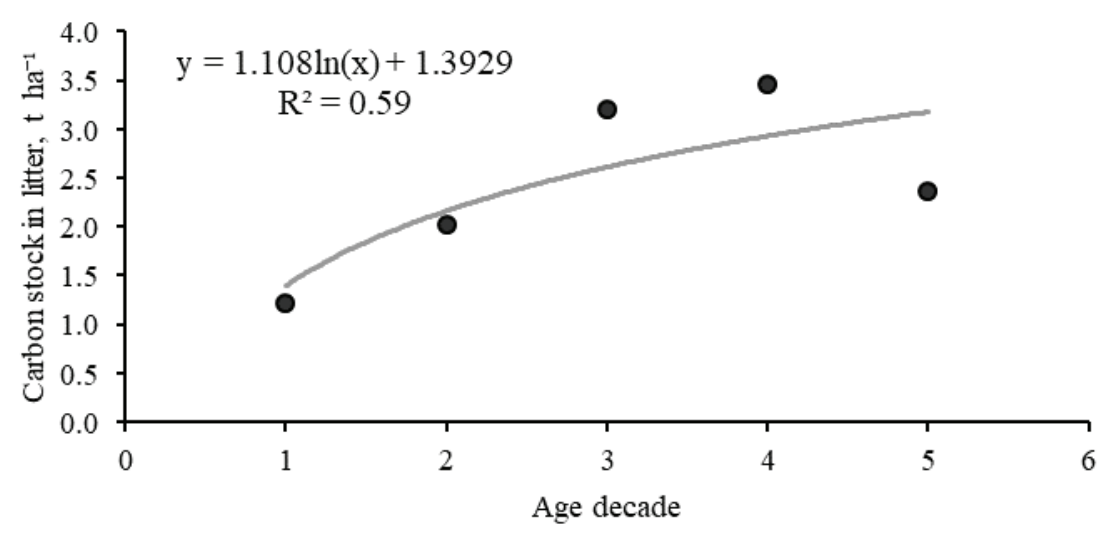

Figure 1. Stand age and average carbon stock in litter in afforested lands.

is $2.02 \pm 0.02 \mathrm{t} \mathrm{ha}^{-1}$. This means that application of the default approach by the Intergovernmental Panel on Climate Changes (IPCC) 2006 guidelines (Eggleston et al., 2006), respectively, use of 20 years transition period for this carbon pool would lead to significant overestimation of $\mathrm{CO}_{2}$ removals in afforested lands. Latvia is currently using much more conservative approach -150 years transition period for the litter, as well as dead wood carbon pools, assuming that 2 rotations of trees are necessary to reach the average values of carbon stock (Ministry of the Environment, 2019). The study approves that this approach, in spite of being very conservative, increases accuracy of carbon stock changes in litter estimations.

The regression povided in Figure 1 can be used for projections of short term (4...5 decades) carbon stock changes in the litter pool in afforested lands. For projection of long term changes, it should be extended with data from mature and second rotation forests, where the rate of carbon accumulation in litter may increase. The Number of black alder (Alnus glutinosa (L.) Gaertn.), ash (Fraxinus excelsior L.) and oak (Querkus robur L.) dominant NFI plots is insufficient to estimate carbon stock in litter in afforested lands.

In the forest land, remaining forest average carbon stock in litter is 5 times larger in comparison to afforested lands - $11.07 \pm 0.05 \mathrm{t} \mathrm{ha}^{-1}$. Strong correlation is found between carbon stock in litter and age of forests, particularly, in coniferous forests and when average values of all species are compared $\left(\mathrm{R}^{2}=0.85\right)$; however, in grey alder, ash and oak stands this correlation is even negative. Summary of

\section{Carbon stock in litter in forest land remaining forest representing different age decades and dominant tree species ( $\left.\mathbf{C ~ h a} \mathbf{~ h a ~}^{-1}\right)$}

\begin{tabular}{|c|c|c|c|c|c|c|c|c|}
\hline $\begin{array}{c}\text { Age } \\
\text { decade }\end{array}$ & Aspen & Birch & Grey alder & Spruce & Black alder & Ash, oak & Pine & $\begin{array}{c}\text { Other } \\
\text { species }\end{array}$ \\
\hline 1 & $7.32 \pm 0.02$ & $10.93 \pm 0.01$ & $3.34 \pm 0.01$ & $8.79 \pm 0.03$ & $10.85 \pm 0.1$ & $6.99 \pm 0.56$ & $17.41 \pm 0.06$ & $1.85 \pm 0.51$ \\
\hline 2 & $3.43 \pm 0.02$ & $6.88 \pm 0.01$ & $3.38 \pm 0.01$ & $8.77 \pm 0.02$ & $6.5 \pm 0.06$ & $5.19 \pm 0.36$ & $14.22 \pm 0.04$ & $3.72 \pm 0.2$ \\
\hline 3 & $3.04 \pm 0.06$ & $6.42 \pm 0.01$ & $3.75 \pm 0.02$ & $11.52 \pm 0.03$ & $7.41 \pm 0.28$ & - & $16.48 \pm 0.08$ & $2.28 \pm 0.14$ \\
\hline 4 & $7.38 \pm 0.36$ & $7.3 \pm 0.02$ & $4.57 \pm 0.02$ & $11.01 \pm 0.02$ & $6.09 \pm 0.07$ & $1.94 \pm 0.61$ & $17.53 \pm 0.12$ & $6.48 \pm 0.46$ \\
\hline 5 & $8.94 \pm 0.12$ & $9.16 \pm 0.01$ & $4.05 \pm 0.01$ & $15.41 \pm 0.02$ & $8.38 \pm 0.09$ & $2.67 \pm 0.64$ & $16.33 \pm 0.07$ & $2.3 \pm 0.25$ \\
\hline 6 & $6.84 \pm 0.05$ & $7.47 \pm 0.01$ & $0.92 \pm 0.03$ & $14.71 \pm 0.03$ & $7.92 \pm 0.04$ & $5.91 \pm 3.73$ & $19.13 \pm 0.03$ & - \\
\hline 7 & $6.25 \pm 0.04$ & $6.87 \pm 0.01$ & $2.98 \pm 0.21$ & $11.93 \pm 0.04$ & $10.58 \pm 0.1$ & $2.78 \pm 0.68$ & $18.91 \pm 0.02$ & $2.77 \pm 0.41$ \\
\hline 8 & $8.00 \pm 0.13$ & $8.39 \pm 0.02$ & $3.55 \pm 2.04$ & $15.84 \pm 0.06$ & $8.34 \pm 0.13$ & $1.28 \pm 0.52$ & $20.46 \pm 0.02$ & - \\
\hline 9 & $4.34 \pm 0.57$ & $7.18 \pm 0.05$ & - & $16.27 \pm 0.12$ & $5 \pm 0.78$ & $10.89 \pm 3.33$ & $20.13 \pm 0.02$ & - \\
\hline 10 & $12.45 \pm 4.99$ & $5.98 \pm 0.18$ & - & $16.21 \pm 0.18$ & $8.75 \pm 1.45$ & $5.81 \pm 1.98$ & $18.38 \pm 0.02$ & $5.75 \pm 7.47$ \\
\hline 11 & $32.09 \pm 50.49$ & $14.32 \pm 5.08$ & - & $10.89 \pm 0.35$ & - & $5.01 \pm 2.68$ & $20.2 \pm 0.04$ & - \\
\hline 12 & - & $19.98 \pm 35.27$ & - & $16.27 \pm 0.72$ & - & - & $16.23 \pm 0.05$ & - \\
\hline 13 & $57.48 \pm 0$ & - & - & $24.84 \pm 4.43$ & - & - & $16.04 \pm 0.1$ & - \\
\hline 14 & - & - & - & $10.74 \pm 5.27$ & - & - & $15.78 \pm 0.22$ & - \\
\hline 15 & - & - & - & $13.09 \pm 3.57$ & - & - & $14.1 \pm 0.22$ & - \\
\hline
\end{tabular}


the calculation of carbon stock in litter in forest land remaining forest is provided in Table 3. The largest values of carbon stock are found in coniferous forests and mature aspen stands. It is important to note that mature aspen stands are usually coniferous forests with several large aspens forming the largest growing stock in a particular NFI plot. Therefore, large carbon stock in litter in aspen stands also relates to coniferous species.

The study results approve an earlier finding that accumulation of litter and immobilization of nutrients, particularly nitrogen, takes place in mature coniferous forests resulting in shortage of the nutrients and decreased growth rate (Forest Fertilization., 1968; Binkley \& Fisher, 2012).

The carbon stock dynamics in the litter pool depending on the forest age is characterized by polynomial regression (Figure 2), which demonstrates reduction of carbon stock in young stands and increase of carbon in mature forests with following decrease of carbon stock in decaying forests. It is important to note that 100 years old and older stands are mostly represented by coniferous species.

The largest carbon stock in litter is in coniferous stands; significantly smaller it is in deciduous species
(Figure 3). The difference is statistically significant. Similar regularity is found also in afforested lands (Table 2).

The correlation between growing stock and carbon stock in litter is also studied; however, no correlation was found. Statistical analysis shows that the study results can be used to estimate long term impact of species composition on carbon stock in litter, but more data are necessary to estimate the impact of age structure at a species level.

Other task of the study is evaluation of peat depth in order to calculate carbon stock in drained and wet forests organic soils. Nutrient-poor and nutrient-rich organic soils, wet and drained soils, and different dominant species are evaluated separately (Table 4). No significant differences were found depending on growth conditions and dominant species, except pine stands, which are growing on deeper peat soils in nutrient poor conditions. The thinnest peat layer is in aspen and grey alder stands (Figure 4).

In $50 \%$ of sample plots in forests with organic soils surveyed in 2017-2019, peat layer is less than $50 \mathrm{~cm}$ in drained forests, and less than $60 \mathrm{~cm}$ in forests with wet soils. In $18 \%$ of forests with organic soil, according to national definition, it was found that peat

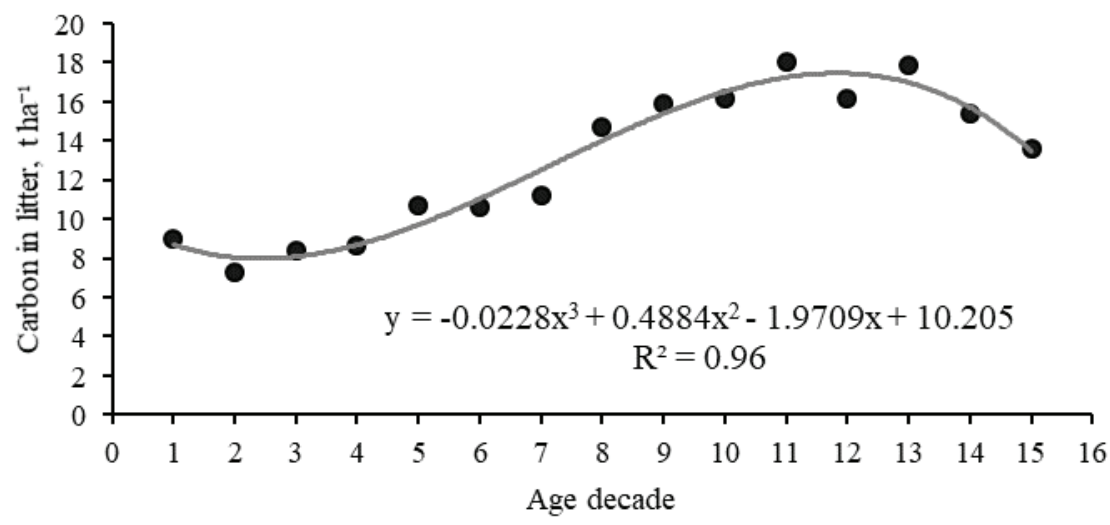

Figure 2. Stand age and average carbon stock in litter in forest land remaining forest.

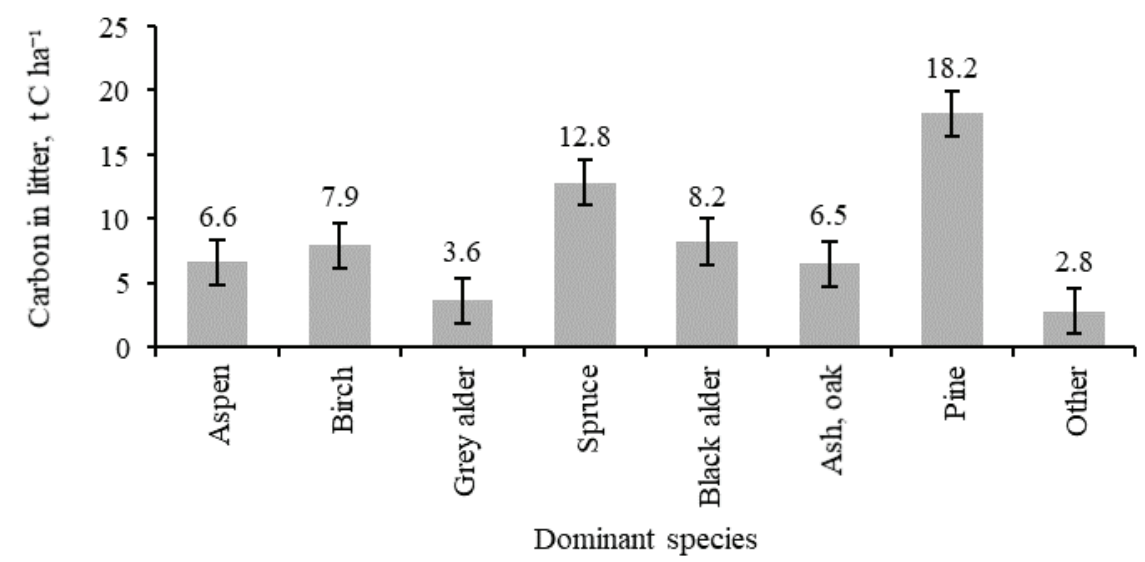

Figure 3. Stand age and average carbon stock in litter in forest land remaining forest. 
Relative peat depth in forests with wet and drained peat soils, $\%$

\begin{tabular}{|l|l|c|c|c|c|c|c|c|}
\hline \multicolumn{2}{|c|}{ Growth conditions } & Aspen & Birch & Grey alder & Spruce & Black alder & Pine & Average \\
\hline \multirow{2}{*}{$\begin{array}{l}\text { Drained } \\
\text { soils }\end{array}$} & nutrient-poor & 50 & 84 & 21 & 37 & - & 75 & 76 \\
\cline { 2 - 10 } & nutrient-rich & 13 & 60 & 27 & 55 & 43 & 33 & 52 \\
\hline \multirow{2}{*}{ Wet soils } & nutrient-poor & 31 & 64 & - & 56 & 65 & 76 & 73 \\
\cline { 2 - 10 } & nutrient-rich & 18 & 60 & 24 & 65 & 35 & - & 37 \\
\hline
\end{tabular}

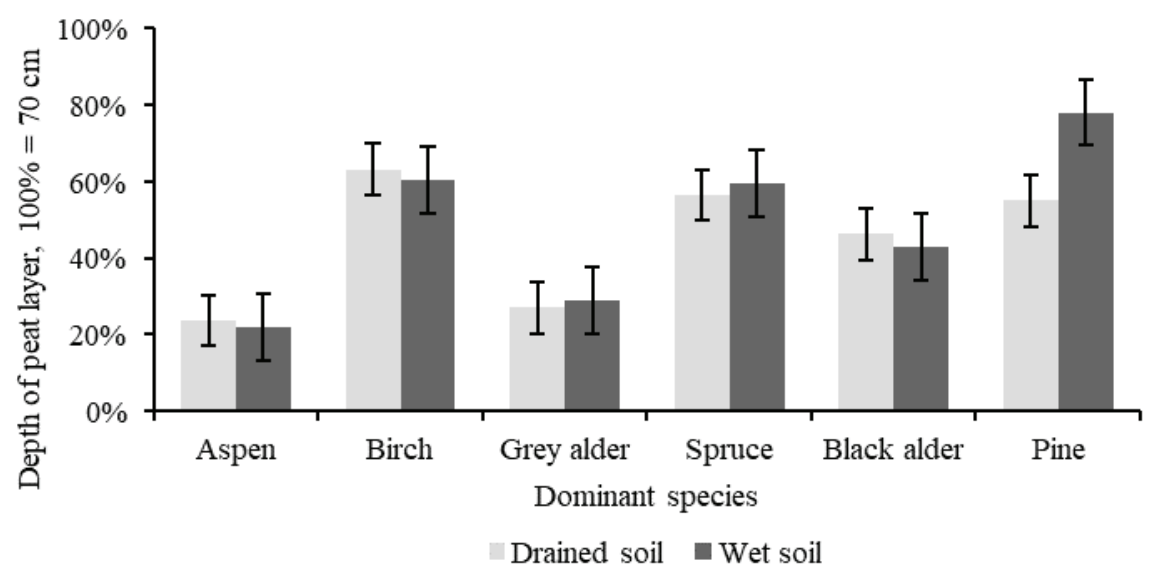

Figure 4. Comparison of peat depth in forest with drained and wet organic soils with different dominant species.

depth is below $20 \mathrm{~cm}$, respectively these soils might not be considered as organic soils according to IPCC definition (Hiraishi et al., 2013). In forests with wet soils in $23 \%$ cases peat layer is less than $30 \mathrm{~cm}$. At the same time in $25 \%$ of forests with drained soil and in $33 \%$ of forests with wet organic soil peat depth is more than $70 \mathrm{~cm}$.

Calculation of carbon stock in soil includes $70 \mathrm{~cm}$ deep layer, excluding potential carbon stock in mineral soil layers underlying peat layer and includes litter layer. Carbon stock in litter in forest stand types with organic soils according to national definition in Latvia is 7.7 mill. t $\mathrm{C}$, including 3.2 mill. $\mathrm{t} \mathrm{C}$ in forests with wet soils and 4.5 mill. $\mathrm{t} C$ forests with drained soils. Carbon stock in soil in forest stand types with organic soils according to national definition is 234 mill. $\mathrm{t} \mathrm{C}$, including 120 mill. t $\mathrm{C}$ in forests with drained soils and 114 mill. t $\mathrm{C}$ in forests with wet soils. Total carbon stock in forests with organic soils according to national definition is 242 mill. t C (Table 5).

It is necessary to extend forest soil monitoring program by inclusion more sample plots representing dry and wet organic soils, which contribute to the most of GHG emissions in LULUCF sector in Latvia (Lazdiņš, 2020; Ministry of the Environment, 2019). In parallel, it is necessary to improve activity data on moisture regime in forests with organic soils, because it is found in several studies, e.g. by Lazdiņš (2020) that groundwater depth does not differ significantly in drained and wet soils at the end of vegetation period.

Summarized data on soil and litter carbon stock in forest stand types with organic soils according to national definitions is shown in Figure 5. Considering relatively small number of plots these values may have significant uncertainty. The largest carbon stock is in pine stands, it is relatively smaller in aspen and grey alder stands due to thin peat layer. Carbon stock in wet soils may be overestimated due to limited data available on the density of organic soil layers in wet forest soils.

Estimated carbon stock in litter and soil in forests with organic soils is by $16 \%$ larger than carbon stock in mineral soils at $0 \ldots 30 \mathrm{~cm}$ depth (Bārdule et al., 2009; Lazdinšs et al., 2013) and is nearly equal to carbon stock in living biomass in forest lands (Ministry of the Environment, 2019). Total carbon stock in forest lands according to the study results is 762 mill. t, including $31 \%$ in organic soils.

The results prove significance of further studies on carbon stock changes in forest soils and accurate evaluation of soils' properties in forest inventories, because organic soils (according to IPCC definition) were found in all growth conditions. This means also that principle of calculation of GHG emissions in forests should be changed from growth conditions based equations to soil characteristics based models to improve accuracy. 
Carbon stock in organic soil and litter in different growth

Table 5 Conditions and dominant species stands (1000 t C)

\begin{tabular}{|c|c|c|c|c|c|c|c|c|c|}
\hline \multicolumn{2}{|c|}{ Growth conditions } & Aspen & Birch & $\begin{array}{l}\text { Grey } \\
\text { alder }\end{array}$ & Spruce & $\begin{array}{l}\text { Black } \\
\text { alder }\end{array}$ & Pine & $\begin{array}{c}\text { Other } \\
\text { species }\end{array}$ & Total \\
\hline \multicolumn{10}{|c|}{ Litter } \\
\hline \multirow{3}{*}{$\begin{array}{l}\text { Drained } \\
\text { soil }\end{array}$} & nutrient-poor & 2.6 & 107.3 & 8.9 & 80.0 & - & 682.7 & 10.4 & 892.0 \\
\hline & nutrient-rich & 97.4 & 1236.1 & 35.7 & 734.3 & 280.7 & 1082.9 & 118.9 & 3586.0 \\
\hline & total & 100.0 & 1343.4 & 44.6 & 814.3 & 280.7 & 1765.6 & 129.3 & 4478.0 \\
\hline \multirow[t]{3}{*}{ Wet soil } & nutrient-poor & 14.0 & 516.9 & 0.0 & 179.6 & 86.4 & 1326.9 & 19.1 & 2142.9 \\
\hline & nutrient-rich & 8.1 & 377.6 & 89.0 & 85.7 & 478.2 & - & 43.4 & 1081.9 \\
\hline & total & 22.2 & 894.5 & 89.0 & 265.2 & 564.6 & 1326.9 & 62.5 & 3224.8 \\
\hline \multicolumn{2}{|l|}{ Sum total } & 122.1 & 2237.9 & 133.6 & 1079.5 & 845.3 & 3092.5 & 191.8 & 7702.8 \\
\hline \multicolumn{10}{|c|}{ Peat at $0-70 \mathrm{~cm}$ depth } \\
\hline \multirow{3}{*}{$\begin{array}{l}\text { Drained } \\
\text { soil }\end{array}$} & nutrient-poor & 347.3 & 8352.9 & 79.9 & 2533.7 & - & 18483.4 & 535.3 & 30332.6 \\
\hline & nutrient-rich & 952.8 & 40768.5 & 1819.4 & 18452.5 & 10018.3 & 15022.2 & 2425.8 & 89459.4 \\
\hline & total & 1300.1 & 49121.4 & 1899.3 & 20986.2 & 10018.3 & 33505.6 & 2961.2 & 119792.0 \\
\hline \multirow[t]{3}{*}{ Wet soil } & nutrient-poor & 240.6 & 16554.3 & 0.0 & 3179.9 & 2203.2 & 56188.8 & 1128.4 & 79495.2 \\
\hline & nutrient-rich & 267.7 & 17813.4 & 1393.8 & 3307.2 & 11566.6 & - & 412.7 & 34761.3 \\
\hline & total & 508.3 & 34367.7 & 1393.8 & 6487.1 & 13769.8 & 56188.8 & 1541.0 & 114256.5 \\
\hline \multicolumn{2}{|l|}{ Sum total } & 1808.4 & 83489.1 & 3293.1 & 27473.3 & 23788.1 & 89694.4 & 4502.2 & 234048.5 \\
\hline \multicolumn{2}{|c|}{ Total litter and soil } & 1930.5 & 85727.0 & 3426.7 & 28552.8 & 24633.4 & 92786.9 & 4694.0 & 241751.3 \\
\hline
\end{tabular}

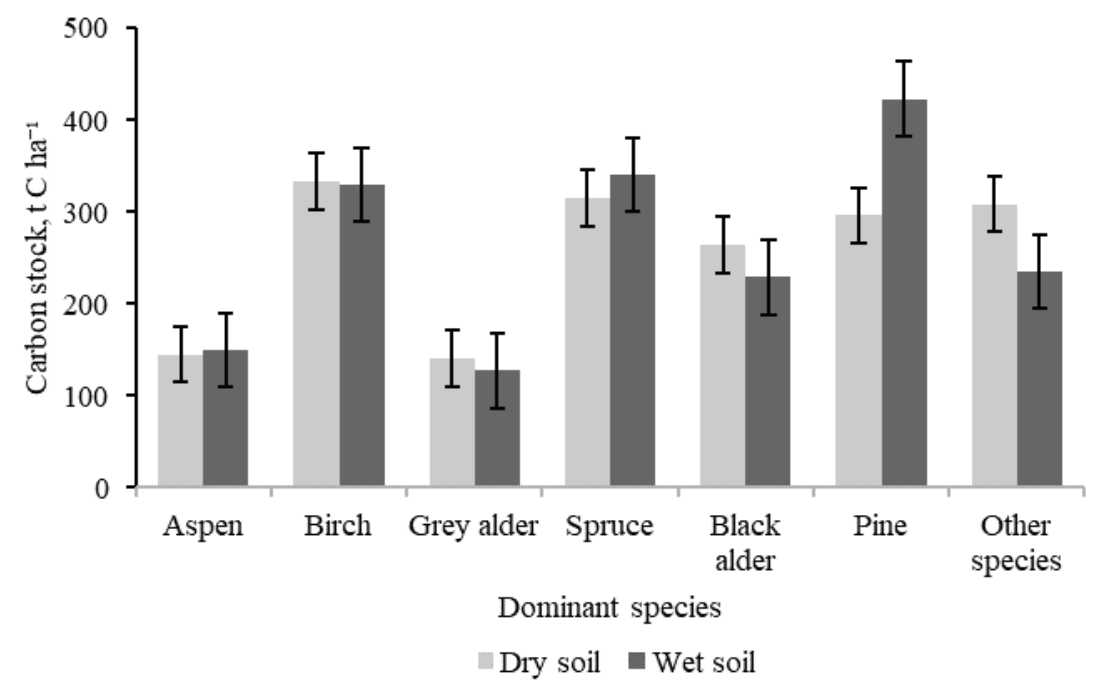

Figure 5. Average soil and litter carbon stock in drained and wet soils in forest stand types with organic soils according to national definition.

\section{Conclusions}

1. The results of the study proves significance of soil carbon pool in organic forest soils in Latvia (31\% of the total carbon stock in forest lands), as well as demonstrate necessity to improve soil density data on wet organic soils, which can have significant impact on GHG emissions in forest lands.

2. The study proves that the conservative approach of calculation of carbon stock changes in litter applied in the Latvia's National GHG inventory avoids overestimation of $\mathrm{CO}_{2}$ removals due to afforestation. Further studies in mature forests and second generation of trees on afforested lands are necessary to improve the soil carbon flux modelling capabilities.

3. Obtained data is sufficient to estimate total carbon stock and long term impact of changes of species composition on litter layer, e.g. growing 
of deciduous trees instead of coniferous trees; however, potential overestimation of presented carbon stock in wet organic soil calculation should be considered.

4. The study demonstrates that the stand type based estimation of soil carbon stock changes may lead to biased estimates due to considerable share of organic soils present in stands classified as with mineral soil.

\section{Acknowledgements}

The measurement data are acquired within the scope of the memorandum between LSFRI Silava and Joint stock company 'Latvia state forests' from 11.10.2011; the data analysis is implemented within the scope of ERAGAS program INVENT project.

\section{References}

Forest Fertilization: Theory and Practice (1968). Knoxville: Tennessee Valley Authority National Fertilizer Development Center.

Bārdule, A., Bāders, E., Stola, J., \& Lazdiņš, A. (2009). Latvijas meža augsṇu īpašību raksturojums demontrācijas projekta BioSoil rezultātu skatījumā (Forest soil characteristic in Latvia according to results of the demonstration project BioSoil). Mežzinātne. 20 (53), 105-124. (in Latvian).

Bērziņa, L., Degola, L., Grīnberga, L., Kreišmane, D., Lagzdiņš, A., Lazdiņš, A., Lēnerts, A., Lupiķis, A., Naglis-Liepa, K., Popluga, D., Rivža, P., \& Sudārs, R. (2018). Siltumnīcefekta gāzu emisiju samazināšanas iespējas ar klimatam draudzīgu lauksaimniecību un mežsaimniecību Latvijā (Possibilities for reducing greenhouse gas emissions with climate-friendly agriculture and forestry in Latvia: a monograph). Jelgava: Latvijas Lauksaimniecības universitāte. (in Latvian).

Binkley, D., \& Fisher, R. (2012). Ecology and Management of Forest Soils. New York: Wiley-Blackwell.

European Comission (2018). COM(2018) 773 final Communication from the Commission to the European Parliament, the European Council, the Council, the European Economic and Social Committee, the Committee of the Regions and the European Investment Bank A clean planet for all a European strategic long-term vision for a prosperous, modern, competitive and climate neutral economy. Brussels: European Commission.

Eggleston, S., Buendia, L., Miwa, K., Ngara, T., \& Kiyoto, T. (2006). 2006 IPCC Guidelines for National Greenhouse Gas Inventories. Agriculture, Forestry and Other Land Use. Japan: Institute for Global Environmental Strategies (IGES).

Hiraishi, T., Krug, T., Tanabe, K., Srivastava, N., Fukuda, M., Troxler, T., \& Jamsranjav, B. (2013). 2013 Supplement to the 2006 IPCC Guidelines for National Greenhouse Gas Inventories: Wetlands. Japan: Intergovernmental Panel on Climate Change.

Lazdiņa, D., Lazdiņ̌s, A., Bebre, I., Lupiķis, A., Makovskis, K., Spalva, G., Sarkanābols, T., Okmanis, M., Krīgere, I., Dreimanis, I., \& Kalniņa, L. (2019). Sustainable and responsible after-use of peat extraction areas. Rīga: Baltijas krasti.

Lazdiņ̌s, A. (2020). Kūdras augsnes Latvijas siltumnīcefekta gāzu bilancē - klimata izmaiṇu mazināšanas izaicinājumi un iespējas (Peat soils in Latvia's greenhouse gas balance - climate change mitigation challenges and opportunities). In Latvijas Universitātes 78. zinātniskā konference 'Biologija', 7 February 2020. Rīga: Latvijas Universitāte. (in Latvian).

Lazdiṇš, A., Bārdule, A., Stola, J., \& Krišāns, O. (2013). Temporary carbon stock changes in forest soil in Latvia. In International Baltic Sea Regional Scientific Conference: Interdisciplinary Research for Higher Socioeconomic Value of Forests, 10-12 June 2013 (pp. 51-52). Salaspils: Latvian State Forest Research Institute 'Silava'.

Lazdiņš, A., Butlers, A., \& Lupiķis, A. (2014). Case study of soil carbon stock changes in drained and afforested transitional bog. In $9^{\text {th }}$ Baltic theriological conference: Forest Ecosystems and Its Management: Towards Understanding the Complexity I, 15 October 2014 (pp. 39-40). Daugavpils: Daugavpils University.

Lazdiņš, A., \& Lupiḳis, A. (2014). Hidrotehniskās meliorācijas ietekme uz CO, emisijām mežaudzēs uz susinātām augsnèm (Impact of hydrotechnical melioration on $\mathrm{CO}_{2}$ emissions from forests on drained soils). Salaspils: Latvijas Valsts mežzinātnes institūts 'Silava'. (in Latvian).

Lazdiņ̌s, A., Lupiķis, A., \& Okmanis, M. (2014). Soil carbon stock change due to drainage of a forest stand growing on a transitional bog. In Extended abstracts of the CAR-ES network meeting in Finland, 20-22 October 2014 (pp. 50-53). Vantaa, Finland: Finnish Forest Research Institute.

Lazdiņš, A., Šñepsts, G., Petaja, G., \& Kārkliņa, I. (2019). Verification of applicability of forest growth model AGM in elaboration of forestry projections for National forest reference level. In Proceedings of the $9^{\text {th }}$ International Scientific Conference 'Rural Development 2019', 26-28 September 2019 (pp. 289-294). Lithuania: Vytautas Magnus University Agriculture Academy. 
Lazdin̄š, A. (2015). Augsnes CO emisiju koeficientu izstrādāšana auglīgām organiskām augsnēm - šaurlapju un platlapju küdreniem (Development of $\mathrm{CO}_{2}$ Emission Factors for Soil in Fertile Organic Soils in Myrtillosa turf. mel. and Oxalidosa turf. mel. forest types). Salaspils: Latvijas Valsts mežzinātnes institūts 'Silava'. (in Latvian).

Ministry of Environmental Protection and Regional Development (2019). Latvia's National Inventory Report Submission under UNFCCC and the Kyoto protocol Common Reporting Formats (CRF) 1990 - 2017. Latvia: Ministry of Environmental Protection and Regional Development of the Republic of Latvia.

Ministry of the Environment. (2019). Greenhouse gas emissions in Estonia 1990-2017. National inventory report. Submission to the UNFCCC Secretariat. Common Reporting Formats (CRF) 1990-2017. Estonia: Ministry of the Environment.

Rogelj, J., Schaeffer, M., Meinshausen, M., Knutti, R., Alcamo, J., Riahi, K., \& Hare, W. (2015). Zero emission targets as long-term global goals for climate protection. Environmental Research Letters. 10(10). DOI: 10.1088/1748-9326/10/10/105007. 